Int. J. Morphol.,

32(1):202-207, 2014

\title{
Evaluation and Clinical Application of Sacral S1 Vestibule Measurements in Chinese Adults
}

\author{
Evaluación y Aplicación Clínica de las Mediciones del Vestíbulo Sacral S1 en Adultos Chinos
}

\author{
Qiang Dong,***; Wei Tian",** \& Baotong Ma**
}

DONG, Q.; TIAN, W. \& MA, B. Evaluation and clinical application of sacral S1 vestibule measurements in Chinese adults. Int. J. Morphol., 32(1):202-207, 2014.

SUMMARY: This study aims to measure the anatomic parameters of the sacral 1 (S1) vestibule in Chinese adults and to discuss their clinical application during iliosacral screw fixation for pelvic posterior ring injury. Three-dimensional computed tomography (CT) reconstructions were performed on 36 individuals, and the parameters of their S1 vestibules were measured. Vestibular width (VW) was $25.15 \pm 2.91 \mathrm{~mm}$, vestibular height $(\mathrm{VH})$ was $20.94 \pm 3.03 \mathrm{~mm}$, and mean vestibular size (VS) was $400.23 \pm 85.11 \mathrm{~mm}^{2}$. The mean angle of superior inclination was $30.85^{\circ} \pm 9.22^{\circ}$, and the mean anterior inclination (AI) was $13.91^{\circ} \pm 6.25^{\circ}$. VW and VS were significantly smaller in females than in males ( $\mathrm{p}<0.05$ ), but no statistical differences were found between the left and right sides. The S1 vestibules of Chinese patients are smaller than those reported for Caucasians. Therefore, the placement of iliosacral screws should be considered carefully based on the size, gender, and ethnicity of the patient. The anatomic parameters of females were much smaller than those of males and close to the minimum requirement for fracture fixation. Therefore, female Chinese patients who need iliosacral screws should undergo preoperative $\mathrm{CT}$ scans to measure S1 vestibule parameters to make individual operational plans.

KEY WORDS: Sacral vestibule anatomy; Sacroiliac joint; Bone screws.

\section{INTRODUCTION}

The sacral vestibule, first proposed by Carlson et al. (2000), refers to the three-dimensional (3D) screw space that is available in the narrowest part of the iliosacral screw channel. The sacral vestibule is located in the transition zone between the sacral wing and sacral body and serves as the entrance to the sacral vertebrae. The vestibule is divided into two components, the $\mathrm{S} 1$ and $\mathrm{S} 2$ vestibules. The smaller S2 vestibule is associated with limited tolerance for screw misdirection, which can increase the risk of nerve injury or spinal canal damage (Routt et al., 1997; Hinsche et al., 2002; van den Bosch et al., 2002). Therefore, S2 vestibules are rarely used for screw replacement. The $\mathrm{S} 1$ vestibule, located above the sacral foramina and between the sacral foramina and the slope of the sacral wing, is the isthmus of the transition zone between the sacral wing and the S1 vertebrae. The sacral wing forms the dome of the vestibule, and the upper margin of the sacral foramina is the bottom of the vestibule. On the front view, the vestibule is dumbbellshaped, but it is an ellipse on the side view.

An in-depth understanding of the anatomy of the sacral vestibule is crucial to treating posterior pelvic ring

\footnotetext{
* Tianjin Medical University, Tianjin, China.

** Department of Orthopedics, Tianjin Hospital, Tianjin, China.
}

injuries with iliosacral screws (Supplementary Fig. 1). The present research imaged the anatomy and measured 36 normal sacra in Chinese adults.

\section{SUBJECT AND METHOD}

Enrolled participants. A total of 36 Chinese adults (19 males and 17 females) had their normal sacrum subjected to a $\mathrm{CT}$ and their sacral vestibules were visualized and measured on both sides, for 72 samples. This study was conducted in accordance with the declaration of Helsinki. This study was conducted with approval from the Ethics Committee of Tianjin Hospital, Tianjin Medical University. Written informed consent was obtained from all participants.

CT scanner and post-processing software. All participants underwent a sacral scan on a spiral CT scanner (SOMATOM Sensation 10, SIEMENS, Germany) with $100 \mathrm{~mA}$ tube current and $120 \mathrm{kV}$ tube voltage. All data were transferred into an image reconstruction system (Syngo CT 2006G, SIEMENS) to complete the post-processing procedure. The slice section was $1.0 \mathrm{~mm}$ and the interval was $1.0 \mathrm{~mm}$. 
CT measurements. The sacral CT data of all participants were reconstructed as $1.0 \mathrm{~mm}$ interval and 1.0 $\mathrm{mm}$ sections to build 3D sacral images (Fig. 1). The sections, which were vertical to the bone in the sagittal plane near the transition zone between the vertebrae of S1 and sacral wing, were saved to take a series of measurements as follows: The area of the sections was measured and the area of the smallest section was considered as the area of the vestibule (VS) (Fig. 2). The length of the long anteroposterior diameter, namely, the width of the vestibule (VW), was measured; the length of the short superior inferior diameter, namely, the height of the vestibule $(\mathrm{VH})$ of the section, was also measured (Fig. 2). The angles of the anterior inclination (AI) and the superior inclination (SI) of the S1 vestibule were measured.

Statistical analysis. SPSS 17.0 was used to perform the statistical analysis. All data are presented as mean \pm standard deviation. A Student's t-test was used to compare the results between different measurements. A $p<0.05$ was considered statistically significant for all statistical analyses.

\section{RESULTS}

The average area (VS) of the S1 vestibules was $400.23 \pm 85.11 \mathrm{~mm}^{2}\left(196.96 \mathrm{~mm}^{2}\right.$ to $\left.607.94 \mathrm{~mm}^{2}\right)$. The average area of the male $\mathrm{S} 1$ vestibules was $428.59 \pm 72.43 \mathrm{~mm}^{2}$ $\left(277.65 \mathrm{~mm}^{2}\right.$ to $\left.607.94 \mathrm{~mm}^{2}\right)$, and that of the female vestibule was $369.25 \pm 89.05 \mathrm{~mm}^{2}$ (196.96 $\mathrm{mm} 2$ to $\left.598.97 \mathrm{~mm} 2\right)$. The females had significantly smaller vestibule areas than males $(\mathrm{p}<0.05$; Table I). The average width $(\mathrm{VW})$ of the $\mathrm{S} 1$ vestibules was $25.15 \pm 2.91 \mathrm{~mm}(17.25 \mathrm{~mm}$ to $31.30 \mathrm{~mm})$. The average VW of the male S1 vestibules was $26.82 \pm 2.49$ $\mathrm{mm}(21.49 \mathrm{~mm}$ to $31.30 \mathrm{~mm})$, and that of the female vestibules was $23.71 \pm 2.93 \mathrm{~mm}(17.25 \mathrm{~mm}$ to $31.06 \mathrm{~mm})$. The average height $(\mathrm{VH})$ of the $\mathrm{S} 1$ vestibules was $20.94 \pm 3.03$ $\mathrm{mm}(14.73 \mathrm{~mm}$ to $25.42 \mathrm{~mm})$. The average $\mathrm{VH}$ of the male $\mathrm{S} 1$ vestibules was $21.08 \pm 2.66 \mathrm{~mm}$ (14.73 $\mathrm{mm}$ to $24.83 \mathrm{~mm}$ ), and that of the female vestibules was $20.78 \pm 3.29 \mathrm{~mm}(15.56$ $\mathrm{mm}$ to $25.42 \mathrm{~mm}$ ). The average SI angle was $30.85^{\circ} \pm 9.22^{\circ}$ $\left(17^{\circ}\right.$ to $\left.45^{\circ}\right)$. The average SI angle in males was $30.72^{\circ} \pm 9.14^{\circ}$

Table I Comparison of S1 vestibule anatomical parameters in male and female.

\begin{tabular}{|c|c|c|c|c|c|c|c|c|c|c|}
\hline \multirow{2}{*}{ Parameters } & \multicolumn{4}{|c|}{ Male $(n=19)$} & \multicolumn{4}{|c|}{ Female (n=17) } & \multirow{2}{*}{$\mathbf{t}$} & \multirow{2}{*}{$\frac{P}{\text { M vs F }}$} \\
\hline & - & $\mathbf{S}$ & Min & $\operatorname{Max}$ & - & $\mathbf{S}$ & Min & Max & & \\
\hline VW-left & 26.89 & 1.29 & 21.49 & 31.30 & 23.74 & 1.591 & 18.46 & 31.06 & 2.188 & 0.036 \\
\hline VH-left & 21.15 & 2.02 & 17.44 & 24.73 & 20.73 & 2.22 & 15.56 & 23.58 & 0.597 & 0.554 \\
\hline VS-left & 437.12 & 71.87 & 294.36 & 607.94 & 370.58 & 59.44 & 206.34 & 580.12 & 3.005 & 0.005 \\
\hline SI-left & 30.58 & 10.00 & 17.00 & 45.00 & 31.12 & 8.16 & 18.00 & 44.00 & 0.176 & 0.862 \\
\hline AI-left & 14.37 & 6.63 & 0.00 & 25.00 & 13.82 & 6.32 & 3.00 & 24.00 & 0.252 & 0.803 \\
\hline VW-right & 26.79 & 1.47 & 22.04 & 29.08 & 23.672 & 1.353 & 17.25 & 30.03 & 2.202 & 0.035 \\
\hline VH-right & 21.02 & 2.37 & 14.73 & 24.83 & 20.84 & 2.50 & 16.66 & 25.42 & 0.215 & 0.831 \\
\hline VS-right & 420.92 & 68.92 & 277.65 & 530.10 & 360.16 & 77.77 & 196.96 & 598.97 & 2.486 & 0.018 \\
\hline SI-right & 30.84 & 9.92 & 18.00 & 45.00 & 31.24 & 8.45 & 17.00 & 43.00 & 0.127 & 0.900 \\
\hline AI-right & 14.32 & 6.43 & 0.00 & 22.00 & 13.18 & 5.97 & 2.00 & 22.00 & 0.549 & 0.587 \\
\hline
\end{tabular}

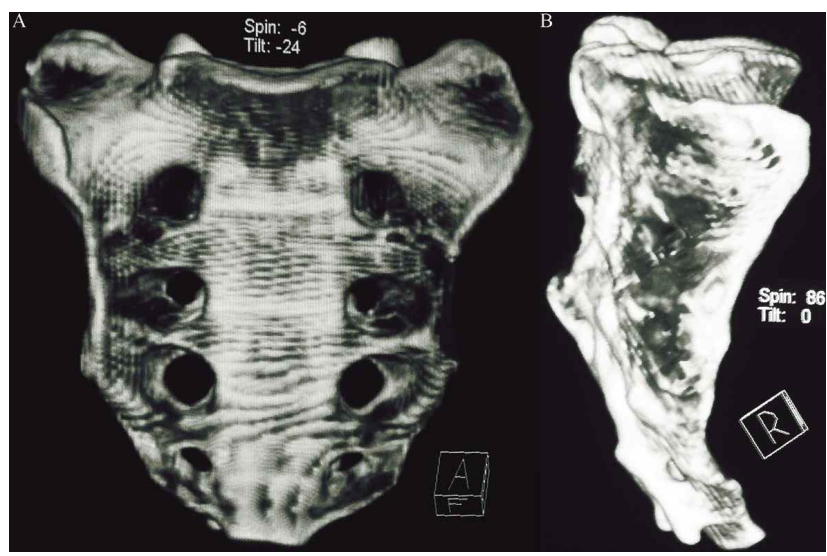

Fig. 1. The anterior-posterior and lateral pictures of sacrum reconstruction.

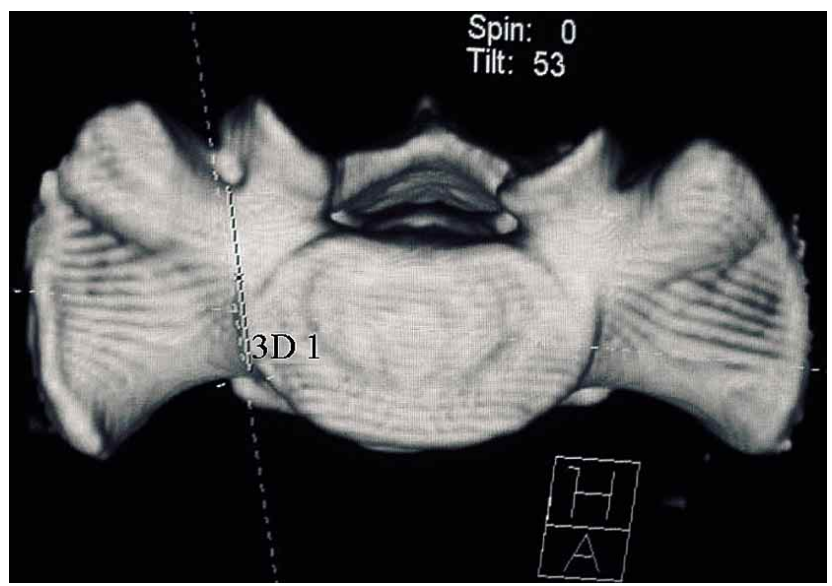

Fig. 2. Measure the parameters of S1 vestibule. 
Table II. Comparison of anatomical parameters of left and right S1 vestibule.

\begin{tabular}{|c|c|c|c|c|c|c|}
\hline Sex & Parameters & $\mathbf{n}$ & - & $\mathbf{S}$ & $\mathbf{t}$ & \begin{tabular}{|c|} 
P \\
L vs R
\end{tabular} \\
\hline \multirow[t]{10}{*}{ Male } & VW-left & 19 & 26.89 & 1.29 & \multirow{2}{*}{0.346} & \multirow{2}{*}{0.733} \\
\hline & VW-right & 19 & 26.79 & 1.47 & & \\
\hline & VH-left & 19 & 21.15 & 2.02 & \multirow{2}{*}{0.453} & \multirow{2}{*}{0.656} \\
\hline & VH-right & 19 & 21.02 & 2.37 & & \\
\hline & VS-left & 19 & 437.12 & 71.87 & \multirow{2}{*}{1.965} & \multirow{2}{*}{0.065} \\
\hline & VS-right & 19 & 420.92 & 68.92 & & \\
\hline & SI-left & 19 & 30.58 & 10.00 & \multirow{2}{*}{1.424} & \multirow{2}{*}{0.172} \\
\hline & SI-right & 19 & 30.84 & 9.92 & & \\
\hline & AI-left & 19 & 14.37 & 6.63 & \multirow{2}{*}{0.181} & \multirow{2}{*}{0.858} \\
\hline & AI-right & 19 & 14.32 & 6.43 & & \\
\hline \multirow[t]{10}{*}{ Female } & VW-left & 17 & 23.74 & 1.591 & \multirow{2}{*}{0.167} & \multirow{2}{*}{0.869} \\
\hline & VW-right & 17 & 23.672 & 1.353 & & \\
\hline & VH-left & 17 & 20.73 & 2.22 & \multirow{2}{*}{0.290} & \multirow{2}{*}{0.775} \\
\hline & VH-right & 17 & 20.84 & 2.50 & & \\
\hline & VS-left & 17 & 370.58 & 59.44 & \multirow{2}{*}{1.619} & \multirow{2}{*}{0.125} \\
\hline & VS-right & 17 & 360.16 & 77.77 & & \\
\hline & SI-left & 17 & 31.12 & 8.16 & \multirow{2}{*}{0.416} & \multirow{2}{*}{0.683} \\
\hline & SI-right & 17 & 31.24 & 8.45 & & \\
\hline & AI-left & 17 & 13.82 & 6.32 & \multirow{2}{*}{1.649} & \multirow{2}{*}{0.119} \\
\hline & AI-right & 17 & 13.18 & 5.97 & & \\
\hline
\end{tabular}

$\left(17^{\circ}\right.$ to $\left.45^{\circ}\right)$, and the average SI angle in females was $31.17^{\circ} \pm 8.33^{\circ}\left(17^{\circ}\right.$ to $\left.43^{\circ}\right)$. The average AI angle was $13.91^{\circ} \pm 6.25^{\circ}\left(0^{\circ}\right.$ to $\left.25^{\circ}\right)$. The average AI angle in males was $14.35^{\circ} \pm 6.47^{\circ}\left(0^{\circ}\right.$ to $\left.25^{\circ}\right)$, and the average $\mathrm{AI}$ angle in females was $13.57^{\circ} \pm 6.33^{\circ}\left(2^{\circ}\right.$ to $\left.24^{\circ}\right)$ (Table II).

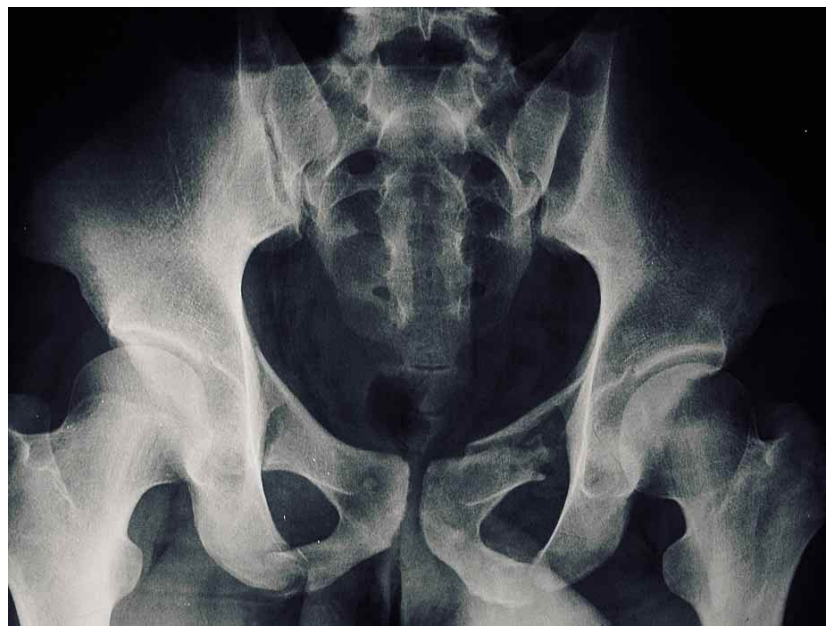

Fig. 3. Male, 24 years old, pelvic fracture because of traffic accident.

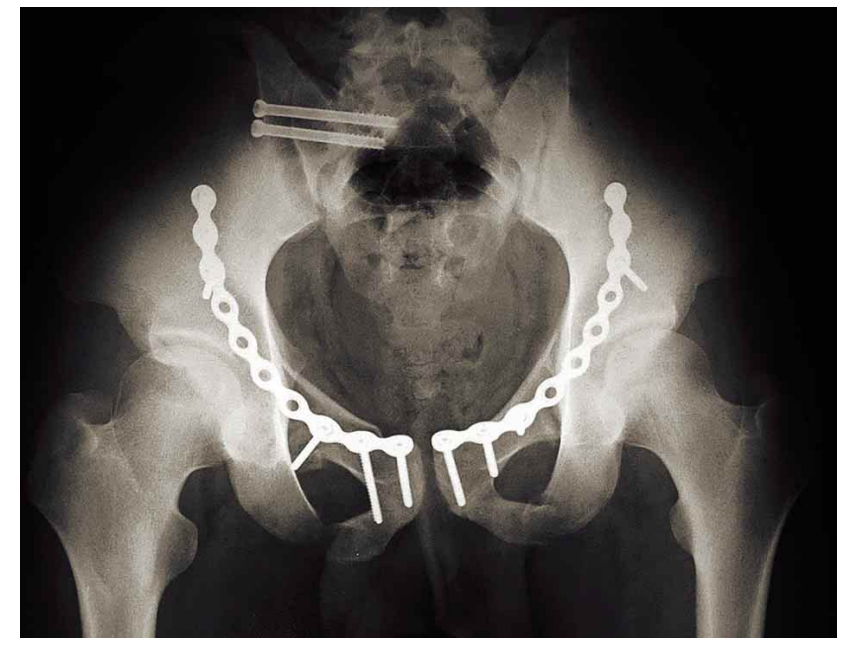

Fig. 4. The patient had the operation seven days after injury. The fracture of pelvic anterior ring was fixed with reconstruction plate, while the posterior ring injury (iliosacal joint dislocation) was fixed with iliosacal screws. X-ray shows the fractures had the anatomical reduction.

\section{DISCUSSION}

Posterior pelvic ring injuries include sacral fractures, sacroiliac complex factures or dislocations, iliac fractu- 
res, or a combination of these injuries (Reilly et al., 2003). Many fixation methods are currently used to treat posterior pelvic ring injuries clinically (Sagi et al., 2004; Schildhauer et al., 2002, 2003; Yinger et al., 2003; Ziran et al., 2003; Vanderschot et al., 2001; Kobbe et al., 2012), and the iliosacral screw (ISS) technique (Ponsen et al., 2006) has been widely used (Cole et al., 1996; Shuler et al., 1995; Sciulli et al., 2007; Gardner \& Chip Routt, 2010; Gardner et al., 2009; Zwingmann et al., 2010; Kim et al., 2012; Oh et al., 2008) because of its reliable fixation strength, small wound, decreased bleeding, and low infection rate. Mears \& Velyvis (2003) described the pelvis as a "three-column structure." ISS establish effective fixation between the middle and posterior columns that properly fits biomechanical characteristics (Figs. 3 and 4). However, the ISS technique requires high precision and has strict requirements for the direction and location of screws. In addition, the operation has to be adjusted according to the pelvic anatomy of each patient. Otherwise, improper positioning of screws might damage nerves and blood vessels. Such damage is caused by screws penetrating the screw channel, fixation failure, or complications from bone cuts, screw bending, or screw facture within the screw channel (Routt et al.; Altman et al., 1999; Ricci et al., 2003; Collinge et al., 2005). Therefore, surgeons who perform the operation must understand the anatomy and the spatial configuration of sacral screw channels (Gardner \& Chip Routt; Zwingmann et al.; Mendel et al., 2012). The sacral vestibule, which is the narrowest part of the screw channel, is crucial for this operation.

Carlson et al. measurements indicated that the average area of the vestibule is $330 \mathrm{~mm} 2$ to $630 \mathrm{~mm} 2$ (534 $\mathrm{mm} 2$ ) in males and $450 \mathrm{~mm} 2$ in females. The anteroposterior diameter of the outlet of the S1 vestibule is larger than its superoinferior diameter. The angle of the SI ranged from $19^{\circ}$ to $45^{\circ}$ and the angle of $\mathrm{AI}$ ranged from $0^{\circ}$ to $25^{\circ}$. Noojin et al. (2000), measured the vestibules of 13 adults ( 6 men and 7 women) via CT and found that the average VW of all specimens was $28.05 \mathrm{~mm}(22.10 \mathrm{~mm}$ to $34.00 \mathrm{~mm})$ and the VH was $27.76 \mathrm{~mm}(22.80 \mathrm{~mm}$ to $35.90 \mathrm{~mm})$. Racial differences in sacral anatomy, especially among Chinese adults, could lead to unsatisfactory treatment results with a high risk of complications. Consequently, vestibule measurements from Chinese adults should be analyzed to determine whether different races have significant differences and to address the clinical significance of individual vestibule measurement.

The VW and VS of the S1 vestibule showed significant differences $(\mathrm{p}<0.05)$ between male and female subjects, but $\mathrm{VH}$ was not significantly different $(\mathrm{p}>0.05)$. The width and area of the $S 1$ vestibule in males' were larger than those of in females. The proper location to insert iliosacral screws was parallel to the long diameter with the inclination angle of the vestibule; therefore, VW and VS are very important references for the operation. Given that both the VW and the VS of females were smaller than those of males, the insertion location, direction of the screw, and the position relationships between the screws are particularly limited for female patients. No significant difference in vestibule measurements was observed on the left and the right side of the body. The vestibule contralateral to the sacral fracture can be measured as a reference for the operation and can be used to determine the feasibility of the operation and the number of screws necessary for fixation.

Compared with previous reports, the anatomical parameters of the vestibules of Chinese adults were generally smaller than those of Caucasians. The VS of both Chinese males and females was about $20 \%$ smaller than that of Europeans and Americans. Thus, standards for operations need to be adjusted based on the individual characteristics of the patient, including ethnicity. Smaller screws are recommended for patients with smaller vestibules, as long as strength is sufficient. Ebraheim et al. (1997) suggested that the screw should be at least $5 \mathrm{~mm}$ away from the cortical edge to ensure patient safety. Based on this standard, the following conclusions were drawn: the smallest bone area for safely inserting two screws is $318.10 \mathrm{~mm} 2$ if a $6.5 \mathrm{~mm}$ hollow pulling screw is used, and the smallest transverse diameter of the section area is $23 \mathrm{~mm}$ with the smallest vertical diameter of $16.5 \mathrm{~mm}$. The smallest bone area required for the safe insertion of one screw is $203.72 \mathrm{~mm} 2$, with both the smallest transverse diameter and the vertical diameter at $16.5 \mathrm{~mm}$. Considering the sacral vestibule is the narrowest part of the $3 \mathrm{D}$ available screw space in the iliosacral screw channel, we can use the anatomical parameters of the vestibule as the minimum measurements for feasibly inserting different numbers of screws. The average vestibule width, height, and area in both sexes were all higher than the lowest requirements for inserting two $6.5 \mathrm{~mm}$ screws. Therefore, the sacral vestibule of Chinese adults generally allows the use of two iliosacral screws for fixation. Analyzing the data by gender, we found that VW, the anteroposterior diameter, was $23.74 \pm 1.59 \mathrm{~mm}$ in females, which is slightly larger than the lowest requirement for inserting two $6.5 \mathrm{~mm}$ screws. However, the VS of some women was smaller than the lowest requirement with the smallest vestibule area $(196.96 \mathrm{~mm} 2)$, even lower than the lowest required area for safely inserting a single screw. Therefore, special attention should be given to female patients who undergo iliosacral screw fixation. Routine CT scans or other imaging examinations should be conducted to obtain the specific anatomical parameters of the sacral vestibule of the patient and determine whether the vestibule area and long axis length allow safe insertion of one screw. 
The anatomical parameters of the S1 vestibule of Chinese adults in the current study were generally smaller than those previously reported for other adults. The area of the vestibule was approximately $20 \%$ smaller than that found in previous studies, which indicates that more attention and accuracy are necessary for operations in this region. The anatomical parameters of the sacral S1 vestibule of females were significantly smaller than those of the males and close to the lowest requirement for fracture fixation (with two iliosacral screws). Therefore, female patients should undergo CT scans or other imaging examinations to measure the sacral anatomical parameters of the S1 vestibule for a more careful and precise operation.

DONG, Q.; TIAN, W. \& MA, B. Evaluación y aplicación clínica de las mediciones del vestíbulo sacral S1 en adultos chinos. Int. J. Morphol., 32(1):202-207, 2014.

RESUMEN: El estudio tuvo como objetivo medir los parámetros anatómicos del vestíbulo sacral 1 (S1) en individuos adultos chinos y discutir su aplicación clínica durante la fijación de tornillo iliosacral por lesiones del anillo pélvico posterior. Se realizaron reconstrucciones de tomografía computarizada tridimensional (TC) en 36 individuos y se midieron los parámetros de sus vestíbulos S1. El ancho vestibular (AV) fue $25,15 \pm 2,91 \mathrm{~mm}$, la altura vestibular fue $20,94 \pm 3,03 \mathrm{~mm}$ y el tamaño medio vestibular (TV) fue 400,23 $\pm 85,11 \mathrm{~mm}{ }^{2}$. El ángulo medio de inclinación superior fue $30,85^{\circ} \pm 9,22^{\circ}$ e inclinación anterior media fue $13,91^{\circ} \pm 6,25^{\circ}$. AV y TV fueron significativamente menores en las mujeres que en los hombres $(\mathrm{p}<0,05)$, sin embargo no se encontraron diferencias estadísticas entre los lados izquierdo y derecho. Los vestíbulos S1 de pacientes chinos son más pequeños que los reportados para los caucásicos. Por lo tanto, la colocación de tornillos iliosacros debe ser considerada cuidadosamente basada en el tamaño, el sexo y origen étnico del paciente. Los parámetros anatómicos de las mujeres eran significativamente más pequeños que los de los hombres y cercanos al requerimiento mínimo para la fijación de fracturas. Por lo tanto, pacientes de sexo femenino chino que requieren tornillos iliosacros deben ser sometidos a tomografías computarizadas preoperatorias para medir los parámetros del vestíbulo S1 a con el objetivo de programar un plan operativo individual.

PALABRAS CLAVE: Anatomía del vestíbulo del sacro; Articulación Sacro-iliaca; Tornillos para huesos.

\section{REFERENCES}

Altman, D. T.; Jones, C. B. \& Routt, M. L. Jr. Superior gluteal artery injury during iliosacral screw placement. J. Orthop. Trauma, 13(3):220-7, 1999.

Carlson, D. A.; Scheid, D. K.; Maar, D. C.; Baele, J. R. \& Kaehr, D. M. Safe placement of S1 and S2 iliosacral screws: the "vestibule" concept. J. Orthop. Trauma, 14(4):264-9, 2000.

Cole, J. D.; Blum, D. A. \& Ansel, L. J. Outcome after fixation of unstable posterior pelvic ring injuries. Clin. Orthop. Relat. Res., (329):160-79, 1996.

Collinge, C.; Coons, D. \& Aschenbrenner, J. Risks to the superior gluteal neurovascular bundle during percutaneous iliosacral screw insertion: an anatomical cadaver study. J. Orthop. Trau$m a$, 19(2):96-101, 2005.

Ebraheim, N. A.; Xu, R.; Biyani, A. \& Nadaud, M. C. Morphologic considerations of the first sacral pedicle for iliosacral screw placement. Spine (Phila Pa 1976), 22(8):841-6, 1997.

Gardner, M. J. \& Chip Routt, M. L. Jr. The antishock iliosacral screw. J. Orthop. Trauma, 24(10):e86-9, 2010.

Gardner, M. J.; Farrell, E. D.; Nork, S. E.; Segina, D. N. \& Routt, M. L. Jr. Percutaneous placement of iliosacral screws without electrodiagnostic monitoring. J. Trauma, 66(5):1411-5, 2009.
Hinsche, A. F.; Giannoudis, P. V. \& Smith, R. M. Fluoroscopybased multiplanar image guidance for insertion of sacroiliac screws. Clin. Orthop. Relat. Res., (395):135-44, 2002.

Kim, J. W.; Oh, C. W.; Oh, J. K.; Lee, H. J.; Min, W. K.; Kyung, H. S.; Yoon, S. H. \& Mun, J. U. Percutaneous iliosacral screwing in pelvic ring injury using three-dimensional fluoroscopy. $J$. Orthop. Sci., 18(1):87-92, 2012.

Kobbe, P.; Hockertz, I.; Sellei, R. M.; Reilmann, H. \& Hockertz, T. Minimally invasive stabilisation of posterior pelvic-ring instabilities with a transiliac locked compression plate. Int. Orthop., 36(1):159-64, 2012.

Mears, D. C. \& Velyvis, J. Surgical reconstruction of late pelvic post-traumatic nonunion and malalignment. J. Bone Joint Surg. Br., 85(1):21-30, 2003.

Mendel, T.; Radetzki, F.; Wohlrab, D.; Stock, K.; Hofmann, G. O. \& Noser, H. CT-based 3-D visualisation of secure bone corridors and optimal trajectories for sacroiliac screws. Injury, 44(7):957-63, 2012.

Noojin, F. K.; Malkani, A. L.; Haikal, L.; Lundquist, C. \& Voor, M. J. Cross-sectional geometry of the sacral ala for safe insertion of iliosacral lag screws: a computed tomography model. J. Orthop. Trauma, 14(1):31-5, 2000. 
Oh, C. W.; Kim, P. T.; Kim, J. W.; Min, W. K.; Kyuung, H. S.; Kim, S. Y.; Oh, S. H. \& Ihn, J. C. Anterior plating and percutaneous iliosacral screwing in an unstable pelvic ring injury. J. Orthop. Sci., 13(2):107-15, 2008.

Ponsen, K. J.; Joosse, P.; Schigt, A.; Goslings, J. C. \& Luitse, J. S. Internal fracture fixation using the Stoppa approach in pelvic ring and acetabular fractures: technical aspects and operative results. J. Trauma, 61(3):662-7, 2006.

Reilly, M. C.; Bono, C. M.; Litkouhi, B.; Sirkin, M. \& Behrens, F. F. The effect of sacral fracture malreduction on the safe placement of iliosacral screws. J. Orthop. Trauma, 17(2):8894, 2003.

Ricci, W. M.; Padberg, A. M. \& Borrelli, J. The significance of anode location for stimulus-evoked electromyography during iliosacral screw placement. J. Orthop. Trauma, 17(2):95-9, 2003.

Routt, M. L. Jr.; Simonian, P. T. \& Mills, W. J. Iliosacral screw fixation: early complications of the percutaneous technique. J. Orthop. Trauma, 11(8):584-9, 1997.

Sagi, H. C.; Ordway, N. R. \& DiPasquale, T. Biomechanical analysis of fixation for vertically unstable sacroiliac dislocations with iliosacral screws and symphyseal plating. J. Orthop. Trauma, 18(3):138-43, 2004.

Schildhauer, T. A.; McCulloch, P.; Chapman, J. R. \& Mann, F. A. Anatomic and radiographic considerations for placement of transiliac screws in lumbopelvic fixations. J. Spinal Disord. Tech., 15(3):199-205, 2002.

Schildhauer, T. A.; Ledoux, W. R.; Chapman, J. R.; Henley, M. B.; Tencer, A. F. \& Routt, M. L. Jr. Triangular osteosynthesis and iliosacral screw fixation for unstable sacral fractures: a cadaveric and biomechanical evaluation under cyclic loads. $J$. Orthop. Trauma, 17(1):22-31, 2003.

Sciulli, R. L.; Daffner, R. H.; Altman, D. T.; Altman, G. T. \& Sewecke. J. J. CT-guided iliosacral screw placement: technique and clinical experience. AJR Am. J. Roentgenol., 188(2):W18192, 2007.

Shuler, T. E.; Boone, D. C.; Gruen, G. S. \& Peitzman, A. B. Percutaneous iliosacral screw fixation: early treatment for unstable posterior pelvic ring disruptions. J. Trauma, 38(3):4538, 1995.

van den Bosch, E. W.; van Zwienen, C. M. \& van Vugt, A. B. Fluoroscopic positioning of sacroiliac screws in 88 patients. J. Trauma, 53(1):44-8, 2002.

Vanderschot, P.; Meuleman, C.; Lefèvre, A. \& Broos, P. Trans iliacsacral-iliac bar stabilisation to treat bilateral lesions of the sacro-iliac joint or sacrum: anatomical considerations and clinical experience. Injury, 32(7):587-92, 2001.
Yinger, K.; Scalise, J.; Olson, S. A.; Bay, B. K. \& Finkemeier, C. G. Biomechanical comparison of posterior pelvic ring fixation. J. Orthop. Trauma, 17(7):481-7, 2003.

Ziran, B. H.; Smith, W. R.; Towers, J. \& Morgan, S. J. Iliosacral screw fixation of the posterior pelvic ring using local anaesthesia and computerised tomography. J. Bone Joint Surg. Br., 85(3):411-8, 2003.

Zwingmann, J.; Konrad, G.; Mehlhorn, A. T.; Südkamp, N. P. \& Oberst, M. Percutaneous iliosacral screw insertion: malpositioning and revision rate of screws with regards to application technique (navigated vs. Conventional). J. Trauma, 69(6):1501-6, 2010.

\section{Correspondence to: \\ Wei Tian \\ Tianjin Medical University \\ Tianjin 300070 \\ CHINA}

Phone: +86-13820737331

Fax: +86-22-60362990

Email: weitiancn@163.com

Received: $19-10-2013$

Accepted: 13-12-2013 